\title{
Failure to Eject
}

National Cancer Institute

\section{Source}

National Cancer Institute. Failure to Eject. NCI Thesaurus. Code C133511.

Problem associated with the inability to remove or discharge device from the location of use. 